\title{
CORPORATE TRUSTEE'S CONFLICT OF INTEREST
}

The increasing importance of the large trust company has led to a need for reassessment of the traditional rule that a trustee is surcharged, irrespective of good faith, for any loss to the trust or profit to the trustee resulting from transactions involving a "conflict of interest." The corporate trustee's control over a large number of trust funds, and its extensive operations in a complex business world, on the one hand enable it to have the facilities, experience and contacts necessary for expert management of trust estates, and yet on the other hand render it especially vulnerable to situations of conflicting interest. Thus strict enforcement of the traditional rule might well unduly hamper a trust company's actions and deprive beneficiaries of many of the benefits of modern trust management. ${ }^{2}$ A group of cases arising out of the depression, ${ }^{2}$ and two more recent decisions of Judge Learned Hand, ${ }^{4}$ indicate that courts might revise their approach by considering conflict-of-interest cases in light of the remoteness of the conflict and the presence or absence of good faith.

Courts have imposed liability in some situations where the conflict of interest was so remote as to render it improbable that the trustee did act, or would have acted, for his own benefit. Thus a trustee has been held subject to surcharge where one of its eighteen directors was President and on the board of a corporation in which the trust held stock, ${ }^{5}$ and where the trust estate retained shares in the trustee. ${ }^{6}$ Courts also impose liability where, despite a close conflict

12 Scott, Trusts $\$ \$ 170.25,206$ (2d ed., 1956); 3 Bogert, Trusts and Trustees $\$ 543$ (1935); Rest., Trusts $\$ 170$ (1935). See generally Scott, The Fiduciary Principle, 37 Calif. L. Rev. 539 (1949); Scott, The Trustee's Duty of Loyalty, 49 Harv. L. Rev. 521 (1936).

${ }^{2}$ Some courts have recognized this problem. In re Binder's Estate, 137 Ohio St. 26, 35, 27 N.E.2d 939, 946 (1940) ("Trust companies perform a great service in the business world and the law must not make the rules of conduct governing them so onerous that they may not function, but it must demand that high sense of honor and measure of integrity which loyalty requires..."); Phelan v. Middle States Oil Corp., 220 F.2d ·593, 604 (C.A.2d, 1955) (L. Hand, J.) ("The law ought not make trusteeship so hazardous that reponsible individuals and corporations will shy away from it."). See Mills, The Advantages of a Corporate Fiduciary, 24 Miss. L. J. 456 (1953); Niles and Schwartz, Breach of Trust-Recent Developments, 20 N.Y.U.L.Q. Rev. 165 (1944).

${ }^{3}$ Cases discussed at notes $17-25$ infra.

1 Phelan v. Middle States Oil Corp., 220 F.2d 593 (C.A.2d, 1955); Dabney v. Chase National Bank, 196 F.2d 668 (C.A.2d, 1952), discussed in note 39 infra.

5 Manchester v. Cleveland Trust Co., 95 Ohio App. 201, 114 N.E.2d 242 (1953).

62 Scott, Trusts $\$ 170.15$ (2d ed., 1956); 3 Bogert, Trusts and Trustees $\$ 489$ (1935); Scott, Retention of Its Own Shares by a Corporate Trustee, 57 Harv. L. Rev. 601 (1944). The most far-reaching case in this area is City Bank Farmers Trust Co. v. Cannon, 291 N.Y. 125, 51 N.E.2d 674 (1943). For a criticism of its reasoning, see Niles and Schwartz, Breach of TrustRecent Developments, 20 N.Y.U.I.Q. Rev. 165 (1944). Professor Scott observes: "It is quite true that under ordinary circumstances there is in fact no actual conflict of interest; but there is a possibility that circumstances may arise in which there is a conflict of interest. The rule of undivided loyalty is based upon this possible conflict." 2 Scott, Trusts $\$ 170.15$, at p. 1232 (2d ed., 1956) (emphasis added). Retention may be authorized by statute or by the governing instrument, ibid.; 3 Bogert, supra. 
of interest, it is still improbable that the trustee did in fact act for his own benefit. Thus a trustee has been surcharged where there was a specific finding that it acted in good faith, ${ }^{7}$ or where it performed brokerage services of a kind it was qualified to do, charging the trust the standard fee. ${ }^{8}$ The cases cannot be adequately explained on the ground that the difficulty of proving self-dealing might allow guilty trustees to escape liability were proof of actual misconduct required: liability has been imposed in conflict-of-interest cases where it would have been relatively simple to prove the presence or absence of bad faith in the trustee's actions. ${ }^{9}$

The approach of these cases is embodied in the "no further inquiry" rubric, first announced by the New York Court of Appeals in 1886:10

The law ... does not stop to inquire whether the contract or transaction was fair or unfair. It stops the inquiry when the relation is disclosed ... . without undertaking to deal with the question of abstract justice in the particular case.11

7 E.g., Overfield v. Pennroad Corp., 42 F.Supp. 586 (E.D. Pa., 1941), aff'd 146 F.2d 889 (C.A.3d, 1944); Thruston v. Nashville \& American Trust Co., 32 F.Supp. 929 (D. Tenn., 1940); Old Colony Trust Co. v. Mabbett, 334 Mass. 412, 135 N.E.2d 914 (1956); Albright v. Jefferson City Nat'l Bank, 292 N.Y. 31, 53 N.E.2d 753 (1944). Cf. Magruder v. Drury, 235 U.S. 106 (1914); Ball v. Hopkins, 263 Mass. 260, 167 N.E. 338 (1929); In re Carter's Estate, 6 N.J. 426, 78 A.2d 904 (1951); Parsons v. Wysor, 180 Va. 84, 21 S.E.2d 753 (1942); Old Settlers Club of Milwaukee County v. Haun, 245 Wis. 213, 13 N.W.2d 913 (1944).

${ }^{8}$ In Magruder v. Drury, 235 U.S. 106 (1914), a leading case, a trustee bought notes for the trust estate through his own brokerage firm; he was surcharged for the firm's commission even though the notes "cost the estate not a penny more than if the transactions had been with some other firm or individual." Id., at 118. The Court pointed out that "It makes no difference that the estate was not a loser. . . . It is the relation of the trustee to the estate which prevents his dealing in such way as to make a personal profit for himself." Id., at 120. Accord: In re Downing's Estate, 162 Pa. Super. 354, 59 A.2d 903 (1948); In re Dimond, 70 Ohio App. 457, 46 N.E.2d 788 (1943); Bold v. Mid-City Trust, 279 Ill.App. 365 (1935). Joliet Trust Co. v. Ingalls, 276 Ill.App. 445 (1935); In re Roches' Will, 245 App.Div. 192, 281 N.Y.Supp. 77 (4th Dep't, 1935).

- Where the trustee has charged the trust for buying securities of the type which he has had experience in handling, proof of bad faith would be readily obtainable by a reference to the going rates. Where the trustee has deposited funds with itself, bad faith would be easily established by a showing that the bank was declining or that the funds were being kept on deposit for unreasonable periods with a consequent loss of interest. Where the trustee has failed to earmark a group of securities bought with its own and with trust funds, bad faith could, for example, be demonstrated by proof that the trustee has subsequently attributed appreciated securities to itself, and depreciated securities to the trust estate.

${ }^{10}$ Munson v. Syracuse, Geneva \& Corning R.R. Co., 103 N.Y. 58, 8 N.E. 355 (1886).

Il Id., at 74, 358. Accord: Alabama Fidelity Mortgage \& Bond Co. v. Dubberly, 198 Ala. 545, 73 So. 911 (1916); Garrett v. Reid-Cashion Land \& Cattle Co., 34 Ariz. 245, 270 Pac. 1044 (1928); Smith v. Pacific Vinegar \& Pickle Works, 145 Cal. 352,78 Pac. 550 (1904); Morgan v. King, 27 Colo. 539, 63 Pac. 416 (1900); Perdue v. McKenzie, 194 Ga. 356, 21 S.E.2d 705 (1942); Fine v. Saul, 183 Ga. 309, 188 S.E. 439 (1936); Clark v. Clark, 167 Ga. 1, 144 S.E. 787 (1928); Hill v. Rich Hill Coal Mining Co., 119 Mo. 9, 24 S.W. 223 (1893); Sacajawea Lumber \& Shingle Co. v. Skookum Lumber Co., 116 Wash. 75, 198 Pac. 1112 (1921); Parsons v. Tacoma Smelting \& Refining Co., 25 Wash. 492, 65 Pac. 765 (1901). The New York cases are gathered and the rule criticized in Haggerty, Conflicting Interests of Estate Fiduciaries in New York and the "No Further Inquiry" Rule, 18 Fordham I. Rev. 1 (1949). 
The primary purpose of this rule is to deter trustees from occupying positions in which they might be tempted to violate their trust. ${ }^{12}$ However, while this purpose might seem to require indiscriminate application of the rule to all situations in which such temptation is possible, it is clear that some limitations are necessary. Thus, whenever a bank with deposit and stock departments becomes a trustee, there is a possibility that it will be tempted to deal with itself in depositing funds and purchasing stock. Application of the strict rule would obviously be impractical, if banks are to remain in the trust business. Another limitation appeared in a group of depression cases involving large losses on trust assets carried in the trustee's own name. While agreeing with the beneficiaries that this practice constituted a breach of trust, the courts nevertheless refused to surcharge. The language of a leading Pennsylvania case, Guthrie's Estate, ${ }^{13}$ is typical of the reasoning used:

The exceptants have at most suffered what may be only a temporary loss, and that solely because of the economic conditions of the times. ... They would nonetheless ignore the good faith and sound business judgment of the trustees, who have made full disclosure of their conduct of the trust, and would take advantage for their own gain of a technical violation of the law....14

Guthrie's Estate was soon followed by the courts of Connecticut, ${ }^{15}$ Massachusetts, ${ }^{16}$ Florida, ${ }^{17}$ Nebraska, ${ }^{18}$ Alabama, ${ }^{19}$ Michigan, ${ }^{20}$ Virginia, ${ }^{21}$ Washington $^{22}$ and New Hampshire. ${ }^{23}$ While these cases rest primarily on lack of causa-

12 Meinhard v. Salmon, 249 N.Y. 458, 164 N.E. 545 (1928) (Cardozo, J.); Shanley v. Fidelity Union Trust Co., 5 N.J.Misc. 783, 784, 138 Atl. 388, 388 (1927) ("The rule is . . reflected in the supplicating words of the Lord's Prayer, 'Lead us not into temptation.' ").

13320 Pa. 530, 182 Atl. 248 (1936).

${ }^{14}$ Id., at 538, 252. This case was followed in Pennsylvania by at least three other cases involving substantially the same point. Dillon's Estate, $324 \mathrm{~Pa} .252$, 188 Atl. 134 (1936); Harton's Estate, 331 Pa. 507, 1 A.2d 292 (1938); Swindell's Estate, 332 Pa. 181, 3 A.2d 2 (1938). But cf. Quest's Estate, 324 Pa. 230, 233, 188 Atl. 137, 138 (1936).

${ }^{15}$ Chapter House Circle v. Hartford Nat. Bank \& Trust Co., 121 Conn. 558, 578, 186 Atl. 543,550 (1936). ("The plaintiff is entitled to recover only such loses as resulted from the fact that the defendant took the note and mortgage in its individual name, not losses due to general business conditions, which would have occurred even though the mortgage had been taken and held in the name of the defendant as trustee.") Accord: Lyman v. Stevens, 123 Conn. 591, 197 Atl. 313 (1938).

${ }^{16}$ Springfield Safe Deposit \& Trust Co. v. First Unitarian Society, 293 Mass. 480, 200 N.E. 541 (1936).

${ }^{17}$ Voorhies v. Blood, 127 Fla. 337, 173 So. 705 (1937). This case goes a step beyond the others, for here the trustee had purchased mortgages for the estate through its own affiliate in addition to having carried them in its own name.

${ }^{18}$ Rotzin v. Miller, 134 Neb. 8, 277 N.W. 811 (1938).

${ }^{19}$ First National Bank of Birmingham v. Basham, 238 Ala. 500, 191 So. 873 (1939); Barker v. First Nat. Bank of Birmingham, 20 F.Supp. 185 (N.D. Ala., 1937).

${ }^{20}$ Potter v. Union \& People's Nat. Bank of Jackson, 105 F.2d 437 (C.A.6th, 1939).

${ }^{21}$ Buckle v. Marshall, 176 Va. 139, 156, 10 S.E.2d 509, 513 (1940).

${ }^{22} \mathrm{Cf}$. In re LeFèvre's Guardianship, 9 Wash.2d 145, 113 P.2d 1014 (1941).

${ }^{23}$ Miller v. Pender, 93 N.H. 1, 34 A.2d 663 (1943). 
tion, ${ }^{24}$ they also suggest the use of good faith as a defense. ${ }^{25}$ It might be argued that these factors should be considered only in earmarking cases. In these cases if the trustee has in fact neither sold the asset and pocketed the proceeds nor substituted for it his own poor investment, ${ }^{26}$ there is not the slightest suspicion that he has profited from the trust. Moreover, there is a high probability that the trustee was motivated by considerations of convenience rather than a desire to make a profit from the trust. ${ }^{27}$ Finally, unless the purchase of the asset was motivated by a plan to place it in the trustee's name so as to pocket the proceeds of a later sale or to claim the asset as the trustee's own investment while putting one of lesser value into the trust estate, it cannot be said that the breach of trust caused the loss. ${ }^{28}$ In other situations of conflict of interest, such

${ }^{24}$ In Pennsylvania, Guthrie's Estate has perhaps been limited to situations in which the trust asset is a participating mortgage. Quest's Estate, $324 \mathrm{~Pa} .230,188$ Atl. 137 (1936). See Rest., Trusts $\$ 179$ (Supp., 1948).

In In re Ryan's Will, 291 N.Y. 376, 52 N.E.2d 909 (1943), the trustee, attempting in good faith to act under a statute allowing limited self-purchase, failed to fulfill the statutory notice requirements, and was surcharged for losses on self-purchased assets. The case is distinguishable on the ground that the breach of trust can be regarded as the self-purchase rather than the failure to give notice.

${ }^{25}$ Three other states during this same period also liberalized the strict rule of liability without expressly using the depression as a rationale. In New Jersey, a trustee was not surcharged for alleged conflict of interests inherent in the following transactions: advancement of trustee's own funds to purchase bonds for its trust estates as a temporary accommodation; subsequent transfer of one of these bonds to the trust estate; and receipt by the trustee of a commission for serving as trustee of the mortgage securing the bond issue mentioned above. Pike v. Camden Trust Co., 128 N.J. Eq. 414, 420, 16 A.2d 634, 638 (1940). The court in Bowden v. Citizens Loan \& Trust Co., 194 Minn. 113, 259 N.W. 815 (1935), allowed a bank to invest in participating first mortgage trust certificates held in its own name as trustee for many trusts and upon which it gained a commission. And in Finley v. Exchange Trust Co., 183 Okla. 167, 80 P.2d 296 (1938), it was held that a trust company may combine uninvested trust funds in one bank deposit and combine funds of different trusts in the same investment.

${ }^{26}$ The substitution danger in the earmarking cases arises from the possibility that the trustee might, for example, invest on the same day $\$ 1000$ of his own and $\$ 1000$ of trust funds in two different securities of the same value; unless he is forced immediately to earmark one as belonging to the trust estate, he may later be tempted to claim the more lucrative security as his own. If the trustee's bookkeeping methods are such that it is apparent, as soon as the purchase is made, which security was bought for the trust, there would seem to be no substantial substitution danger. Even if his records do not reveal this information, the requirement imposed by many states of annual reports disclosing the composition of the trust estate [Uniform Trustees Accounting Act, Commissioner's Prefatory Note, 9C U.L.A. 273 (Supp., 1957); 2 Scott, Trusts $\$ 172$, n. 10 (2d ed., 1956)] would severely limit the profit to be derived from such a substitution; the period of time between the reports, during which the securities could be held without designation of ownership, would not be of sufficient length to produce a substantial relative change in the value of the type of security generally held by trust estates. Thus the substitution danger would not seem to be a strong justification for imposing liability for failure to earmark without a showing of bad faith.

${ }^{27}$ The convenience argument has also led many states to adopt statutes permitting corporate trustees to hold securities in the name of a nominee, 2 Scott, Trusts $\$ 179.5$ (2d ed., 1956); 3 Bogert, Trusts and Trustees $\$ 596$ (1935); Uniform Trusts Act, \$9, 9C U.L.A. 296 (Supp., 1957); and to deposit trust funds in its own banking department, 2 Scott, Trusts $\$ 170.18$ (2d ed., 1956); Uniform Trusts Act, \$4, 9C U.I.A. 294 (Supp., 1957).

${ }^{28}$ But see 3 Bogert, Trusts and Trustees $\$ 596$ (1935), where the author states: "Many courts have been impressed with the argument that the lack of a trust label or tag did not 
as purchase of securities from an affiliate of the trustee, ${ }^{29}$ it is generally more difficult to determine whether the breach caused the loss, ${ }^{30}$ or whether the trustee acted in good faith. ${ }^{31}$ However, it is doubtful that the difficulty of determining these important questions should preclude inquiry; the beneficiaries would be sufficiently protected by the fact that added complexity of proof will make it more difficult for the trustee to discharge the burden of justifying his actions. $^{32}$

The policy of disregarding good faith in a conflict-of-interest case is to protect beneficiaries by forbidding a trustee to occupy a position of temptation. ${ }^{33}$ However, this policy is subject to some doubt. The trustee is always in a position of some temptation by the very fact of managing the funds of another-the fact that the temptation may have been greater in a "conflict-of-interest" situation should not preclude the trustee from showing that he managed to resist it. In addition, the no-further-inquiry rule deprives beneficiaries of many advantages of the trustee's extensive business facilities, the use of which might create a conflict of interest. ${ }^{34}$ It is significant that the policy behind the rule of undivided

have any causal connection with the falling off in value of the securities and have refused to surcharge the trustee. It is believed that this is a regrettable relaxation of [a] very salutory rule. ... Hardship in a few cases should not deter the courts from enforcing the strict common law rule."

${ }^{29}$ Where the corporation is clearly an affiliate of the trustee the courts have uniformly imposed liability. 2 Scott, Trusts $\$ 170.11$ (2d ed., 1956); 3 Bogert, Trusts and Trustees $\$ 484$ (1935); Rest., Trusts $\$ 170$, Comment d (1935); Schwartz, Trustee's Dealings with an Affiliate, 81 Trusts and Estates 377 (1945). But where the relationship is not so substantial, the authorities are in conflict. Compare Old Colony Trust Co. v. Mabbett, 334 Mass. 412, 135 N.E.2d 914 (1956) (no liability where there was only one common director), with In re Carter's Estate, 6 N.J. 426, 78 A.2d 904 (1951) (liability where at different times one director of two or two of three on the investment committee either were or had been affiliated with the corporation which sold assets to the trustee).

${ }^{30}$ The difficult problem here is determining whether the trustee would have purchased similar securities from someone other than the affiliate.

3I That is, a problem would arise as to whether the trustee was in effect "dumping" its own securities on the trust estate or whether the securities were actually purchased by the affiliate for the trust estate. See In re Tuttle's Estate, 162 Misc. 286, 294. N.Y.Supp. 230 (Surr. Ct., 1937).

32 This would be analogous to the rule regarding sales between trusts managed by the same trustee. As stated in 2 Scott, Trusts, $\$ 170.16$ (2d ed., 1956), these transactions will be upheld only if the trustee can justify them as being fair to both trusts.

${ }^{33}$ E.g., Michoud v. Girod, 4 How. (U.S.) 503, 554-55 (1846). In holding an executor liable for purchasing the estate of his testator; the Court said: "In this conflict of interest, the law wisely interposes. It acts not on the possibility, that, in some cases, the sense of that duty may prevail over the motives of self-interest, but it provides against the probability in many cases, and the danger in all cases, that the dictates of self-interest will exercise a predominant influence, and supersede that of duty."

34 The long-standing dispute as to whether a corporate trustee may use its own banking facilities as a temporary convenience to the trust is illustrative in this connection. The arguments are summarized in 2 Scott, Trusts $\$ 170.18$ (2d ed., 1956); 3 Bogert, Trusts and Trustees 
loyalty has never been considered so strong as to preclude waiver of the rule by the settlor. ${ }^{35}$

Although the primary purpose of the no-further-inquiry rule is to protect beneficiaries, it would seem to have a secondary purpose of preserving the integrity of the trust institution by deterring trustees from occupying positions which appear suspicious in the eyes of the community. However, the necessity of proving good faith in a conflict-of-interest case might often be sufficient to deter the trustee from occupying such a position. In addition, the corporate trustee must attract the business of future settlors and therefore has an economic interest in avoiding situations which would damage its reputation in the community.

An argument against the good faith standard is that it increases the amount of litigation involved in trust administration. This argument, however, is subject to the qualification that, in the great majority of cases raising the conflictof-interest question, the trustee is already in court to render an accounting. When a loss has occurred, conflict of interest frequently is only one of many objections raised by the beneficiaries; ${ }^{36}$ to inject the good faith issue is simply to add another issue to a case already in court. Moreover, to the extent that the no-further-inquiry rule is designed to protect trust estates from increased litigation costs, there is a counter-argument that a good faith standard would protect estates from increased administration fees made necessary by the threat of frequent liability under the no-further-inquiry rule. ${ }^{37}$

The Second Circuit has taken another approach to restricting the no-furtherinquiry rule. In Phelan v. Middle States Oil Corp., ${ }^{38}$ plaintiffs complained that a receiver who played a prominent part in the reorganization of the corporation expected to be chosen counsel for the newly-formed corporation, and that this expectation might have influenced his decision to sell a large block of shares to

$\$ 598$ (1935); Deposit of Trust Funds by Corporate Trustee in Own Banking Department, 31 Mich. L. Rev. 532 (1933); Whitmore, Self-Deposit by Trust Companies of Fiduciary Funds, 12 N.C. L. Rev. 350 (1934).

${ }^{25} 2$ Scott, Trusts $\$ 170.9$ (2d ed., 1956); In re Flagg's Estate, 365 Pa. 82, 73 A.2d 411 (1950); In re Balfe's Will, 245 App. Div. 22, 24, 280 N.Y.Supp. 128, 130 (1935) ("The decedent was willing that the trustee should act under conditions of divided loyalty. He had the power and right to so provide. That which he knowingly did with his own property did not impinge public policy.... The only safeguard left to the estate was that the trustee act. honestly and in good faith.").

${ }^{36}$ E.g., In re Ryan's Estate, 291 N.Y. 376, 52 N.E.2d 909 (1943); In re Tuttle's Estate, 162 Misc. 286, 294 N.Y.Supp. 230 (Surr. Ct., 1937); In re Roche's Will, 245 App.Div. 192, 281 N.Y.Supp. 77 (1935); In re Trusteeship of Stone, 138 Ohio St. 293, 34 N.E.2d 755 (1941); In re Binder's Estate, 137 Ohio St. 26, 27 N.E.2d 939 (1940).

${ }^{37}$ The fact that trust fees are regulated by statute in most states [3 Scott, Trusts $\$ 242$ ( $2 \mathrm{~d}$ ed., 1956)] does not change this conclusion; any increase in administration costs would tend to generate pressure to raise the statutory rate, drive corporations out of the trust field, or to decrease the quality of the trust service.

220 F.2d 595 (C.A.2d, 1955). 
the new corporation instead of to outsiders. However, no such influence was proven. In refusing to hold the receiver liable, Judge Learned Hand said:

Was that such a conflict as invokes the doctrine? It enables the beneficiary to hold the fiduciary liable for any profits he may make or losses he may cause, in order to deprive him of any inducement that will affect his absolute and disinterested loyalty; and there is no doubt that an expectation or hope of future advantage may do so, even though it is not secured to him as an existing legally protected interest. Therefore, if the doctrine be inexorably applied and without regard to the particular circumstances of the situation, every transaction will be condemned once it be shown that the fiduciary had such a hope or expectation, however unlikely to be realized it may be, and however trifling an inducement it will be, if it is realized. We do not understand that it is to be applied so rigidly, or to so literal an extreme. .. [W]e have to determine the scope of the implementary rule that dispenses with the need of proving that his personal interest had any part in determining the fiduciary's conduct; indeed with a rule that altogether forbids any inquiry whether it had any such part. . . . [I]n a number of situations courts have held that the rule does not apply, not only where the putative interest, though in itself strong enough to be an inducement, was too remote, but also when, though not too remote, it was too feeble an inducement to be a determining motive. ${ }^{39}$

Although Judge Frank dissented on the facts in Phelan, it would appear that he did not oppose the court's reasoning; in an earlier case ${ }^{40}$ he had refused to direct the entry of a summary judgment for the plaintiff, despite an undisputed conflict of interest:

Of course, the courts should not impose impractical obligations on a trustee. Merely vague or remote possible selfish advantages to a trustee are not sufficient to prove such an adverse interest as to bring his conduct into question. in

It would seem that the two factors mentioned by Judge Hand can, when considered together, be incorporated into a good faith approach. "Remoteness of

${ }^{39}$ Id., at 602-3. Accord: Anderson v. Bean, 272 Mass. 432, 172 N.E. 647 (1930); Bullivant v. First National Bank, 246 Mass. 324, 141 N.E. 41 (1923); Pike v. Camden Trust Co., 128 N.J.Eq. 414, 16 A.2d 634 (1940); In re Harton's Estate, 331 Pa. 507, 1 A.2d 292 (1938); Dabney v. Chase National Bank, 196 F.2d 668 (C.A.2d, 1952). The latter case is the first opinion by Judge Hand dealing with the remoteness point. In this case, defendant bank was trustee of two series of unsecured bonds for the bondholding beneficiaries. The two transactions complained of were that the trustee had loaned $\$ 4,000,000$ to the debtor and had collected its loan at a time when it knew the debtor was financially insecure, and the trustee had exchanged securities of the debtor for other securities. The court held that the bank had violated its duty of loyalty in collecting the loan since by so doing it had preferred itself above the bondholders. But as to the exchange of securities, the result turned expressly on the remoteness of the conflict, Judge Hand saying: "However, it is not every possibility, however remote, of a conflict of interest between a trustee and his beneficiary which will forbid his entering into a transaction with a third person. . . . Pushed with relentless logic, a possible conflict of interest can be conjured up out of all sorts of situations in which persons of normal scruple would feel no hesitation to go ahead." Id., at 675.

${ }^{40}$ York v. Guaranty Trust Co., 143 F.2d 503 (C.A.2d, 1944), rev'd on other grounds, 326 U.S. 99 (1945), rehearing denied 326 U.S. 806 (1945).

41 York v. Guaranty Trust Co., 143 F.2d 503, 514 (C.A.2d, 1944). 
the conflict" appears to mean the probability that the trustee could profit from the situation; and "feebleness" of the inducement, the size of the profit to be obtained. The two together determine the single question of whether the particular facts of the case indicate a substantial possibility that the trustee would violate his trust. Where no such possibility exists, the trustee should not be held liable unless the beneficiaries can sustain the burden of showing bad faith. ${ }^{42}$

12 Cf. Pine v. White, 175 Mass. 585, 56 N.E. 967 (1900).

\section{APPRECIATION DAMAGES FOR SELF-PURCHASE BY TRUSTEE WITH POWER OF SALE}

When a trustee with power of sale ${ }^{1}$ sells trust property to himself in breach of trust, the beneficiary has alternative remedies. Unless the property is held by a bona fide purchaser, the beneficiary may compel reconveyance. If it can be shown that a bona fide purchaser has intervened, reconveyance will be denied; but irrespective of this showing, it is clear that the beneficiary may recover either the amount by which the value of the property at the time of the trustee's purchase exceeded the purchase price, or the trustee's profits on the transaction. ${ }^{2}$ It is not clear, however, that the beneficiary is confined to these remedies; some authority exists for allowing him the additional option of recovering "appreciation damages" _ the present value of the property less the trustee's

1 Where the trustee lacks power of sale, appreciation damages are clearly proper, for the reason that, had the trustee not violated his duty to retain, the appreciated property would still be in the trust estate. 2 Scott, Trusts $\$ 208$ (2d ed., 1956); 1 Rest., Trusts $\$ 208$ (1935). A possible objection to this result is that it allows the beneficiary to use the courts for "speculation." See note 21 infra.

2 The beneficiary's options are listed in 2 Scott, op. cit. supra note 1 , at $\$ \S 170.2,206$; 3 Bogert, Trusts and Trustees $\S 484$ (1935).

There exists the possibility of an additional option: following the trustee's profits into their product. To do so would require at least that the trustee consciously acted wrongfully, 2 Scott, op. cit. supra note 1 , at $\$ 507$, and that the proceeds could be isolated from the trustee's general assets. Locke v. Old Colony Trust Co., 289 Mass. 245, 193 N.E. 892 (1935). See notes 8 and 19 infra.

${ }^{3}$ Treatise authority for the imposition of appreciation damages can be found in Scott and the Restatement. Neither authority, however, is free from equivocation; in the Restatement, in fact, the equivocation is so strong that it might be cited as contrary authority.

In 2 Scott, op. cit. supra note 1 , at $\$ 206$ (Liability for Breach of Duty of Loyalty), at page 1532, Scott states: "If the trustee sells trust property to himself individually, and subsequently resells the property to a third person, the beneficiaries have the option of charging him with the value of the property at the time of sale with interest, or with the value of the property at the time of the suit, or they can hold him accountable for the proceeds." (emphasis added.) Nevertheless, in section 170.2 (Duty of Loyalty: Remedies of the Beneficiaries) there is no mention of appreciation damages.

Section 205(h) of the Restatement provides: "If the trustee commits a breach of trust, he is chargeable with ... (c) any profit which would have accrued to the trust estate if he had not committed such breach of trust." Under the language of $\S 205$ (c), appreciation damages can be justified only if it is assumed (1) that had the trustee not first sold to himself, he would 